УДК 378.14

DOI: https://doi.org/10.35387/od.2(20).2021.153-159

Туманова Юлія Володимирівна

- викладач ЗВО ВСП «Класичний фаховий коледж Сумського державного університету», аспірантка фракультету технологічної $і$ профресійної освіти національного педагогічного університету імені О. Довженка
Tumanova Yuliia - Teacher of the Classical Professional College of Sumy State University, Graduate Student of the Faculty of Technological and Vocational Education of Hlukhiv National Pedagogical University named after Oleksandr Dovzhenko

ORCID iD: https://orcid.org/0000-0003-3454-4826

E-mail: tumanovakon1304@gmail.com

\title{
ІННОВАЦІЇ У ФОРМУВАННІ ІНФОРМАЦІЙНОЇ КУЛЬТУРИ МОЛОДШИХ БАКАЛАВРІВ ГАЛУЗІ ТЕХНІЧНИХ НАУК (НА ПРИКЛАДІ ІНФОРМАЦІЙНО-КОМУНІКАЦІЙНИХ ТЕХНОЛОГІЙ)
}

Анотація. Автором оглядової статті зазначено, що провідними тенденціями розвитку в сучасному світі стали інформатизація суспільства та комп'ютеризація всіх галузей людської діяльності. Доведено, що найважливіша роль у соціальному розвитку сучасного суспільства належить інформації. Технологічний прогрес передбачає використання електронної інформації на всіх етапах підготовки фрахівців різного рівня, зокрема і майбутніх молодших бакалаврів галузі технічних наук.

Обгрунтовано доцільність підготовки висококваліфікованих фахівців, які володіють інфрормаційною культурою. Підкреслено, що оволодіння знаннями та вміннями використання інфоормаційно-комунікаційних технологій навчання стало важливим чинником професійної підготовки майбутніх молодиих бакалаврів галузі технічних наук. Зазначено, що використання інформаційнокомунікаційних технологій уможливлює фрормування таких якостей, як: культура пошуку нової інфрормації й обмін нею, уміння опрацьовувати великі масиви інформації з використанням інформаційних технологій, вести пошук в мережі Інтернет, здатність розуміти важливість толерантності профресійного спілкування, вміння обмінюватись досвідом у сучасних інфрормаційних системах. Актуальність набуття цих якостей зумовлює необхідність фоормування інформаційної культури майбутніх молодших бакалаврів галузі технічних наук засобами інформаційно-комунікаційних технологій.

Наголошено, що у сучасному світі інформаційні технології стали невід'ємною частиною світового економічного та суспільного розвитку людства. У цих реаліях революційних змін вимагає й система навчання. Використання IКT у сучасному освітньому середовищі набуло особливої актуальності, адже нині якісне викладання дисциплін не може відбуватися без використання засобів і можливостей, які надають комп'ютерні технології та Інтернет. Вони дають змогу викладачеві набагато краще подати матеріал, зробити його більш цікавим, швидко перевірити знання 
здобувачів вищої освіти та підвищити їхній інтерес до навчання. Зазначено, що викладач має змогу отримувати найновішу інформацію, активно спілкуватися зі здобувачами вищої освіти та їхніми батьками, колегам та ін. Завдяки цьому підвищується авторитет викладача як носія культури, знань тощо.

Ключові слова: інформація; інфформаційна культура; інфформатизація суспільства; інформаційно-комунікаційні технології; Інтернет; молодший бакалавр.

\section{Tumanova Yuliia}

\section{INNOVATIONS IN FORMING INFORMATION CULTURE OF FUTURE JUNIOR BACHELORS IN THE FIELD OF TECHNICAL SCIENCES ON THE EXAMPLE OF INFORMATION AND COMMUNICATION TECHNOLOGIES}

Abstract. The computerization of society and all branches of human activity has become a leading trend in development of the modern world. Information plays a crucial role in the social development of modern societies. Technological progress requires the use of electronic information in all stages of training at various levels, including future junior bachelors in the field of technical sciences.

There is now a greater need for highly qualified professionals with an information culture. The acquisition of knowledge and skills in the use of information and communication technologies in education has thus become an important factor in the training of future junior bachelors in the field of technical sciences.

Information and communication technologies build such qualities as: a culture of searching and sharing new information, the ability to process large amounts of information using information technologies, Internet search, the ability to understand the importance of tolerance in professional communication, ability to share experiences in modern information systems.

In today's world, information technology has become an integral part of the world's economic and social development. In these realities, the system of education also requires revolutionary change. The topicality of this issue is claimed to be found in today's educational environment, since quality teaching of subjects cannot take place without the use of the means and possibilities provided by computer technology and the Internet. They allow the teacher to present the material much better, make it more interesting, quickly test the knowledge of the applicants of education and increase their interest in studying. The teacher has the opportunity to receive up-to-date information and to communicate actively with colleagues, applicants of education and their parents. This raises the profile of the teacher, and he or she can really be the bearer of culture, knowledge, all things advanced.

Key words: information; information culture; information society; information and communication technology; Internet; Junior bachelor.

Постановка проблеми, їі актуальність. Застарілі методи та засоби навчання, що не відповідають сучасним вимогам і відстають від стрімкого розвитку науково-технічного прогресу, актуалізують нагальність використання викладачами закладів вищої освіти інноваційних методів навчання та впровадження цих технологій в освітньому процесі. Слід 
зазначити, що порушена проблема гостро постає у контексті фрормування професійних умінь і навичок, оскільки для ефективнішого їх засвоєння, освітній процес вимагає використання великої кількості наочних матеріалів та інтерактивних засобів, які в свою чергу позитивно сприяють досягненню навчальної мети (Гуревич, 2012).

Таким чином, ми можемо висунути гіпотезу, що застосування інформаційно-комунікаційних технологій у процесі професійної підготовки майбутніх молодших бакалаврів галузі технічних наук $\epsilon$ ефрективним засобом досягнення освітньої мети.

Аналіз актуальних досліджень і публікацій. Аналіз зарубіжних і вітчизняних досліджень свідчить про те, що проблемі використання в освітньому процесі інформаційно-комунікаційних технологій приділяється досить значна увага. Питанню використання в освітньому процесі інформаційно-комунікаційних технологій присвячені роботи Р.Гуревича, М. Кадемії, С. Гунько, М. Жалдака, Ю. Машбиця, Н. Морзе, Е. Полат, І. Роберт, Ю. Триуса, С. Христочевського та ін. Вплив інформаційнокомунікаційних технологій на зміст і методи навчання досліджували Н. Апатова, В. Клочко (Плахотнюк, 2009).

Підкреслимо, що суттєвий науковий потенціал накопичено в галузі методики використання комп'ютерів в освітньому процесі, що досліджували Н. Балик, Р. Вільямс, О. Гокунь, В. Каймін, К. Маклін, Н. Морзе, Ю. Рамський (Плахотнюк, 2009).

Проте аналіз праць науковців свідчить, що дослідження даного питання в сучасній теорії та практиці виявило існуючі суперечності в невідповідності між достатньо розвиненими вміннями та навичками роботи із засобами інформаційно-комунікаційних технологій здобувачів вищої освіти та недостатнім рівнем сформованості вміння критично аналізувати інформацію, опрацьовувати їі, створювати інформаційні продукти, обмінюватись інформацією та етично спілкуватись з усіма учасниками освітнього процесу (Олійник, 2020).

Мета статті - порівняння позитивних і негативних аспектів використання інформаційно-комунікаційних засобів та їх вплив на культуру сучасного здобувача вищої освіти.

Виклад основного матеріалу дослідження. Інформаційнокомунікаційні технології (IKT) - це сукупність методів і засобів, пов'язаних зі створенням, збиранням, збереженням, опрацюванням, передачею й поданням інформації, що розширює знання та спілкування людей і розвиває їх можливості. До сучасних інформаційно-комунікаційних технологій навчання належать: інтернет-технології, мультимедійні програмні засоби, офісне та спеціалізоване програмне забезпечення (текстові та графічні редактори, програми підготовки презентацій, електронні таблиці тощо), електронні посібники та підручники, системи дистанційного навчання (системи комп'ютерного супроводу навчання), телеконференції (Степанов, 2010).

Як відомо, ІКТ відіграють важливу роль в освітньому процесі Реалії сьогодення свідчать про те, що їх застосування, зокрема:

- забезпечує інтеграційні процеси пізнання; 
- сприяє розвитку інформаційної культури особистості;

- підвищує рівень активності здобувачів вищої освіти;

- розвиває здібності альтернативного та креативного мислення;

- розвиває вміння розробляти стратегії пошуку вирішення практичних завдань;

- дозволяє прогнозувати результати реалізації прийнятих рішень на основі моделювання об'єктів, явищ, процесів, що вивчаються, та їхніх взаємозв'язків (Блистів, 2015).

IКТ дають змогу інтегративно підходити до навчання, - це може ще більше розширити межі взаємодії між дисциплінами певного курсу. 3 використанням IКT реалізується творчий та інтелектуальний потенціал учасників освітнього процесу, їх залучення до сучасних методів отримання і переробки інформації. Застосування мультимедіа на заняттях сприяє збагаченню здобувачів вищої освіти, активізує канали студентського сприйняття, а, отже, сприяє ефективному засвоєнню навчального матеріалу. Під час використання мультимедійних технологій етап мотивації збільшується й має пізнавальне навантаження. Це дуже важливо, оскільки без інтересу до поповнення знань, без активізації уяви та емоцій відсутня творча діяльність здобувача вищої освіти, не формується активно його інформаційна культура (Блистів, 2015).

Поява Інтернету, глобальної комп'ютерної мережі з її практично необмеженими можливостями збирання, збереження, передавання інформації індивідуально кожному користувачеві $€$ прикладом успішної реалізації ІКТ. Інтернет швидко знайшов застосування в системі освіти, показавши величезні можливості для її розвитку. Наразі відбувається накопичення досвіду, пошук шляхів підвищення якості навчання і нових форм використання IКT у різних освітніх процесах. Втім не можна зосереджувати увагу лише на позитивному впливі ІКТ. Слід звернути увагу на деякі важливі моменти з погляду на їх неоднозначний влив і, відповідно, значення. Розглянемо деякі соціокультурні аспекти інформатизації освіти та їх вплив на культуру сучасного здобувача вищої освіти (Блистів, 2015).

Індивідуалізація процесу навчання здобувачів вищої освіти. 3 використанням ІКТ відбувається індивідуалізація процесу навчання, а саме: підвищується рівень активності здобувача вищої освіти, розвивається мислення, формуються вміння виконувати навчальні та практичні завдання. Таким чином, важливо в процесі навчання допомогти майбутньому фахівцеві побудувати свою індивідуальну освітню траєкторію з урахуванням власних здібностей. Але незважаючи на це, індивідуалізація навчання може призвести й до негативних наслідків. Індивідуалізація може ще більше посилити розшарування всередині групи здобувачів вищої освіти на слабких і сильних. Ще одним істотним недоліком може бути «згортання» соціальних контактів, скорочення практики соціальної взаємодії і комунікації (Блистів, 2015).

Створення нових форм взаємодії в процесі навчання. Використання IКT дає можливість збільшити кількість видів і фрорм організації діяльності здобувачів вищої освіти на заняттях і вдома (видача та виконання індивідуальних і групових завдань, проєктних рішень тощо). 
Водночас спостерігається зрушення щодо ролі викладача на заняттях, зниження його авторитету, виховного впливу на студентів (Блистів, 2015).

Вплив інформатизації на сучасну мову. 3 використанням IКT зводиться до мінімуму живе спілкування викладачів і здобувачів вищої освіти, здобувачів освіти між собою. Спілкування відбувається у вигляді «діалогу 3 комп'ютером». Це призводить до того, що здобувачі освіти не отримують достатньої практики спілкування, фрормулювання думки, змінюється стиль фрормулювань і письмового викладу, з'являється сленг, мова спрощується (Блистів, 2015).

Вплив інформатизації на цінності та культурні інтереси сучасних здобувачів вищої освіти. В інформаційному суспільстві легко задовольнити будь-які інформаційні потреби людини. Коли йдеться про моральні цінності та культурні інтереси сучасних здобувачів вищої освіти, вплив інформатизації може призвести до негативних результатів, таких, як: зниження значущості традиційних культурних цінностей (книги, живопис, класична музика, театр), нав'язування масової культури, поява субкультур тощо (Блистів, 2015).

Проблема відбору й фільтрації матеріалу. Свобода в пошуку й використанні інформації може призвести до певних негативних наслідків. При цьому здобувачі вищої освіти часто не здатні правильно використовувати інформацію. Часто нелінійна структура інформації зумовлює «спокусу» йти за пропонованими посиланнями. Невміле використання таких ресурсів відволікає від основної мети (Блистів, 2015).

Проблема переходу до самостійних дій. Найскладніше перейти від роботи з інформаційними технологіями до самостійних професійних дій. Доволі часто використання засобів інформатизації освіти позбавляє здобувачів вищої освіти можливості самостійного проведення дослідів, а це негативно позначається на результатах навчання (Блистів, 2015).

Підміна знань комп'ютерною програмою. Сьогодні поступово відбувається заміна знань навичками з пошуку та отримання необхідної інформації за допомогою комп'ютерних програм. Це, безперечно, істотно спрощує процес навчання здобувача вищої освіти, проте, з іншого боку, означає для здобувача освіти зниження цінності володіння знаннями (Блистів, 2015).

Порушення права інтелектуальної власності. У процесі навчання здобувач вищої освіти отримує доступ до колосальних об'ємів інформації. Копіюючи різні інформаційні продукти (програми, конспекти лекцій, методичні вказівки та рекомендації, підручники в електронному вигляді тощо), здобувачі вищої освіти не замислюються над тим, що в багатьох випадках їх копіювання і використання $€$ прямим порушенням права інтелектуальної власності (Блистів, 2015).

Водночас для ефективного використання інформаційнокомунікаційних технологій під час формування інформаційної культури майбутніх молодших бакалаврів галузі технічних наук науково-педагогічні працівники закладів вищої освіти, розробляючи освітні програми, мають враховувати потребу у формуванні здатності здобувачів вищої освіти до (Олійник, 2020): 
- використання програм-браузерів для вирішення практичних завдань: пошуку інформації (пошукові сервери);

- пошук та опрацювання інформації (текстові, графічні, звукові тощо програмиредактори, а також програми-перекладачі, програмиархіватори тощо), поширення та обміну інформацією за допомогою мережевих програм (електронна пошта, соціальні мережі, засоби YouTube та ін.);

- створення мережевих освітніх та інформаційних ресурсів (сайти, блоги, тестові онлайн редактори, мережеві інтерактивні дошки, сторінки та групи в соціальних мережах);

- навчання спільної діяльності (хмарні технології);

- відпрацювання навичок форматування, редагування, зберігання, передачі, знищення файлів різних форматів (мультимедійних, текстових, графічних, табличних форматів);

- знання основних алгоритмічних структур та їхніх властивостей, основ програмування, види, можливості, основні прийоми роботи в інформаційному середовищі тощо.

Висновки і перспективи подальших досліджень. Враховуючи всі позитивні та негативні моменти використання інформаційнокомунікаційних засобів слід зазначити, що вони $€$ ефективними за умови поєднання з традиційними методами. Отже, можна виокремити переваги використання ІКТ як інноваційного метода формування IК майбутніх молодших бакалаврів галузі технічних наук (Гуревич, 2012): індивідуалізації навчання: кожен обирає і працює в режимі, який його задовольняє; об'єктивність контролю; формування вмінь та навичок для здійснення творчої діяльності; виховання інформаційної культури; доступ здобувачів вищої освіти до банків інформації, можливість оперативно отримувати необхідну інформацію; зростання обсягу виконаних завдань на лекційних та практичних заняттях; розширення інформаційних потоків при використанні глобальної комп'ютерної мережі Internet тощо.

Перспективним напрямом досліджень вважаємо необхідність упровадження в освітній процес у закладах вищої освіти, де здійснюється підготовка майбутніх молодших бакалаврів галузі технічних наук, нових дисциплін, курсів за вибором тощо, мета, завдання і зміст яких будуть спрямовані на фрормування інформаційної культури майбутніх фахівців.

\section{Список використаних джерел}

Блистів, О.М. (2015). Взаємозв'язок інформаційної культури та якості навчального процесу. Вісник Національного університету «Львівська політехніка». Серія: Проблеми економіки та управління, 815, 15-21.

Гуревич, Р.С. (2012). Інформаційні технології навчання: інноваційний підхід: навч. посіб. / за ред. Гуревича Р.С. Вінниця : ТОВ фірма «Планер», 348.

Олійник, В.В. (2020). Формування інформаційної культури майбутніх учителів початкової школи засобами інформаційно-комунікаційних технологій. Інформаційні технології і засоби навчання, 75, 1, 212-224.

Плахотнюк, Г. (2009). Інформаційно-комунікаційні технології навчання як засіб формування інформаційної культури педагога. Інформаційнотелекомунікаційні технології в сучасній освіті: досвід, проблеми, 
перспективи : зб. наук. пр. Ч. 2 / за ред. М. М. Козяра та Н.Г. Ничкало. Львів : ЛДУ БЖД, 218-222.

Степанов, В.Ю. (2010). Інформаційно-комунікаційні технології в сучасній освіті. Вісник Харківської державної академії культури, 30, 173-179.

\section{References (translated and transliterated)}

Blystiv, O.M. (2015). Vzaiemozviazok informatsiinoi kultury ta yakosti navchalnoho protsesu [Interconnection of information culture and quality of the educational process]. Visnyk Natsionalnoho universytetu «Lvivska politekhnika». Seriia: Problemy ekonomiky ta upravlinnia, 815, 15-21 [in Ukrainian].

Hurevych, R.S. (2012). Informatsiini tekhnolohii navchnnia: innovatsiinyi pidkhid: Navchalnyi posibnyk [Information technology teaching: innovative approach]. Vinnytsia : TOV firma «Planer», 348 [in Ukrainian].

Oliinyk, V.V. (2020). Formuvannia informatsiinoi kultury maibutnikh uchyteliv pochatkovoi shkoly zasobamy informatsiino-komunikatsiinykh tekhnolohii [Formation of information culture of future elementary school teachers by means of information and communication technologies]. Informatsiini tekhnolohii i zasoby navchannia - Information technologies and means of training, 75, 1. 212-224 [in Ukrainian].

Plakhotnyuk, H. (2009). Informatsiino-komunikatsiini tekhnolohii yak zasib formuvannia informatsiinoi kultury pedahoha [Information and communication technologies of teaching as a means of forming an educational culture of a teacher]. Informatsiino-komunikatsiini tekhnolohii $v$ suchasnii osviti: dosvid, problemy, perspektyvy : zb. nauk. pr. Ch. 2 : Lviv : LDU BZhD, 218-222 [in Ukrainian].

Stepanov, V.Yu. (2010). Informatsiino-komunikatsiini tekhnolohii v suchasnii osviti [Information and communication technologies in modern education]. Visnyk Kharkivskoi derzhavnoi akademii kultury, 30, 173-179 [in Ukrainian].

УДК 159.9:316.6.

DOI: https://doi.org/10.35387/od.2(20).2021.159-168

Франц Малгожата - кандидат гуманітарних наук, доцент кафедри педагогіки Інституту соціальних наук Вищої школи бізнесу і наук про здоров'я в м. Лодзі, Республіка Польща
Frants Malgozhata - Doctor of Sciences in Pedagogy, Associate Profesor at the Pedagogy Department of the Social Sciences Institute of the College of Business and Health Sciences, Lodz, Poland

ORCID iD: https://orcid.org/0000-0002-0923-4538

E-mail:malgorzatafranc@gmail.com

\section{ROZWÓJ UMIEJĘTNOŚCI KOMUNIKACJI INTERPERSONALNEJ W ZESPOLE PRACOWNICZYM}

\footnotetext{
Анотація. У статmі зазначено, що міжособистісні взаємостосунки залежать від: лінгвістичної компетентності (біологічно зумовленої),
} 